JURNAL RESPIRASI

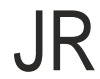

Vol. 1 No. 1 Januari 2015

\title{
Manajemen Pemberian Antibiotik dengan Hasil Uji Kepekaan Resisten
}

\author{
Deny Perdana Putra, Tutik Kusmiati
}

\begin{abstract}
The use of antibiotics in developed countries 13-37\% and 30-80\% in developing countries. Inappropriate use of antibiotics around 40-62\%. There is a relationship between the use of antibiotics in bacterial resistance. Reported a man, 45 years old with a diagnosis of pneumonia + sepsis + DM Type $2+$ hypoalbuminemia + anemia + suspek nephrotic syndrome. Empirical therapy is given Meropenem and Levofloxacin $1 \cdot 7503 \cdot 1$ grams milligrams. Evaluation after empirical therapy showed no improvement clinically and radiologically. The result of the patient 's sputum cultures of Pseudomonas aeruginosa which are resistant to antibiotics tested, therefore the definitive therapy can not be given based on antibiotic susceptibility. The cause of this multifactorial resistance in patients with Pseudomonas resistance to antibiotics through four mechanisms. Therefore, definitive therapy based on local patterns of bacteria and sensitivity test on pneumonia issued by the Department of Microbiology Clinic. Based on the data, antibiotic Piperacillin-tazobactam $4 \cdot 4,5$ grams are then administered. The results of the evaluation of clinical, radiological and laboratory showed significant improvements in patients.
\end{abstract}

Key words: Pneumonia, Pseudomonas aeruginosa, Antibiotic resistance, Sensitivity pattern of bacteria and germs local test

\section{PENDAHULUAN}

Antibiotik merupakan golongan obat yang paling banyak digunakan di dunia terkait dengan banyaknya kejadian infeksi bakteri. Lebih dari seperempat anggaran rumah sakit dikeluarkan untuk biaya penggunaan antibiotik. ${ }^{1} \mathrm{Di}$ Negara yang sudah maju 13-37\% dari seluruh penderita yang dirawat di rumah sakit mendapatkan antibiotik baik secara tunggal maupun kombinasi, sedangkan di negara berkembang $30-80 \%$ penderita yang dirawat di rumah sakit mendapatkan antibiotik. Penggunaan antibiotik dapat menimbulkan masalah apabila penggunaannya tidak rasional. $^{2}$

Berbagai studi menemukan bahwa sekitar 40-62\% antibiotik digunakan secara tidak tepat antara lain untuk penyakit-penyakit yang sebenarnya tidak memerlukan antibiotik. Pada penelitian kualitas penggunaan antibiotik di berbagai bagian rumah sakit ditemukan $30-80 \%$ yang tidak didasarkan pada indikasi. ${ }^{3}$

Penggunaan antibiotik di rumah sakit yang tidak perlu atau berlebihan mendorong berkembangnya resistensi dan kekebalan ganda terhadap bakteri tertentu yang akan menyebar melalui infeksi silang. Terdapat hubungan antara penggunaan (atau kesalahan penggunaan) antibiotik dengan timbulnya resistensi bakteri penyebab infeksi nosokomial. Resistensi tidak dapat dihilangkan, tetapi dapat diperlambat melalui penggunaan antibiotik yang bijak. Penggunaan antibiotik yang terkendali dapat mencegah munculnya resistensi antimikroba dan menghemat penggunaan antibiotik yang pada akhirnya akan mengurangi beban biaya perawatan penderita, mempersingkat lama perawatan, penghematan bagi rumah sakit serta meningkatkan kualitas pelayanan rumah sakit. ${ }^{4}$

Hubungan antara penggunaan obat-obatan antibakteri dan timbulnya resistensi bakteri tampak jelas. Perkembangan resistensi bakteri merupakan masalah yang multifaceted, membentuk suatu hubungan yang kompleks antara penggunaan obat-obat antibakteri, bakteri, dan individu yang menggunakannya. Lingkungan sekitar juga berperan penting di dalam hubungan yang kompleks ini. Obat antibakteri merupakan obat yang tidak hanya mempengaruhi individu yang mengonsumsinya, tetapi juga mempengaruhi lingkungan sekitar, dan individu-individu yang tinggal di lingkungan tersebut. Ketika seseorang mengonsumsi suatu obat antibakteri dengan tidak tepat, hal ini dapat mengakibatkan bakteri tersebut resisten. Bakteri ini dapat berpindah ke orang lain yang tinggal di lingkungan sekitarnya, dan dapat menimbulkan infeksi dengan pilihan antibiotik yang terbatas. ${ }^{5}$ 
Berikut ini kami akan membahas sebuah kasus mengenai manajemen pemberian antibiotik penderita dengan hasil uji kepekaan resisten.

\section{KASUS}

Seorang pria, Tn. S berusia 45 tahun, pekerjaan pedagang, suku jawa, agama islam, bertempat tinggal di Surabaya. Penderita dirujuk dari RS BDH ke IRD RSUD. Dr. Soetomo dengan keluhan sesak nafas. Penderita mengeluh sesak nafas sejak 1 minggu SMRS (sebelum masuk rumah sakit), memberat 1 hari SMRS. Penderita mengeluh batuk dengan dahak warna hijau sejak 1 minggu yang lalu SMRS. Demam dan Batuk tidak didapatkan. Penderita mengeluh bengkak di tangan dan kaki sejak 10 hari yang lalu SMRS dan didapatkan penurunan berat badan dan keringat malam. Nafsu makan masih normal.

Berdasarkan Pemeriksaan Fisik dengan keadaan umum lemah, kesadaran compos mentis, tekanan darah 100/ $70 \mathrm{mmHg}$, nadi $100 \times /$ menit, frekuensi nafas $32 \times /$ menit dan suhu aksiler $37^{\circ} \mathrm{C}$. Kepala dan leher didapatkan anemis, tanpa disertai ikterus maupun sianosis, serta didapatkan dispneu. Tidak tampak pembesaran kelenjar getah bening leher serta tidak didapatkan peningkatan tekanan vena jugularis.

Pada regio toraks, inspeksi didapatkan bentuk dan pergerakan dada yang simetris. Pada palpasi didapatkan fremitus raba yang normal pada seluruh lapangan paru kanan dan kiri. Pada perkusi didapatkan sonor pada seluruh lapangan paru kanan dan kiri. Pada auskultasi didapatkan suara nafas vesikuler di seluruh lapangan paru kanan dan kiri. Didapatkan ronki di seluruh lapangan paru kanan dan 2/3 bawah lapangan paru kiri. Tidak didapatkan suara wheezing.

Pada pemeriksaan jantung, suara jantung $\left(S_{1}\right.$ dan $\left.S_{2}\right)$ tunggal, tidak didapatkan bising jantung maupun irama galop. Pada pemeriksaan abdomen, hepar dan lien tidak teraba, tidak didapatkan massa intraabdomen dan nyeri tekan, serta bising usus dalam batas normal. Pemeriksaan anggota gerak didapatkan edema pada keempat anggota gerak, akral hangat, kering, merah. Tidak didapatkan pembesaran kelenjar getah bening di ketiak maupun lipatan paha

Berdasarkan Pemeriksaan laboratorium darah didapatkan Hb 9,08 g/dL, Hematokrit 30,3\%, Leukosit 18.300, Granulosit 73,7\%, Trombosit 447.000, GDA 162, SGOT 22, SGPT 19, Albumin 1,6, BUN 23, Serum kreatinin1,1, Kalium 4,0, Natrium 138, Klorida 101, CRP Kimia 0,5. Pemeriksaan BGA didapatkan $\mathrm{pH} 7,38, \mathrm{pCO}_{2}$ 57, $\mathrm{pO}_{2} 88$, $\mathrm{HCO}_{3} 33,7, \mathrm{BE} 8,6, \mathrm{SO}_{2} 97 \%, \mathrm{AaDO}_{2}$-10. Pemeriksaan analisis cairan pleura didapatkan Jumlah sel 43, Mono Nuclear 83\%, Poli Nuclear 17\%, glukosa cairan pleura 137, protein cairan pleura 1,0, LDH Cairan pleura 94.

Pada pemeriksaan urin lengkap didapatkan SG 1,026, $\mathrm{pH} 6,5$, Leukosit $25 / \mu \mathrm{L}$, Nitrit negatif, Protein $500 \mathrm{mg} /$ dL, Glukosa 100 mg/dL, Keton 15 mg/dL, Urobilinogen

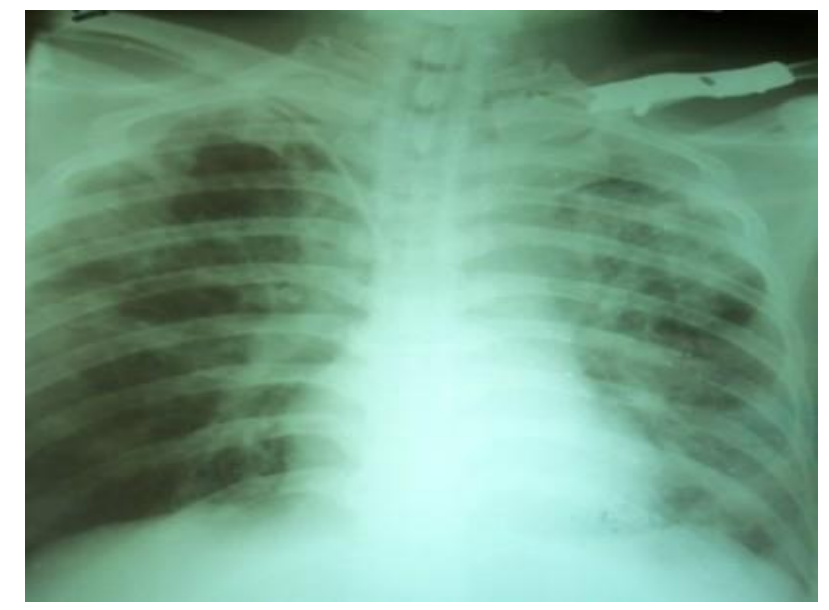

Gambar 1. Foto Toraks

normal, Bilirubin negatif, Eritrosit 150/ $\mu$, Color P.Yellow, RBC $680,50 / \mu \mathrm{L}$, WBC $246,50 / \mu \mathrm{L}$, CAST $37,790 / \mu \mathrm{L}$, BACT $63,10 / \mu \mathrm{L}$. Pemeriksaan prokalsitonin didapatkan nilai 0,200 . Pemeriksaan pewarnaan sputum didapatkan BTA negatif 3x, gram (+) Streptococcus dan pada pemeriksaan kultur sputum aerob didapatkan kuman Pseudomonas aeruginosa yang resisten terhadap semua antibiotik yang diperiksa.

Berdasarkan pemeriksaan foto toraks didapatkan infiltrat di parakardial dan suprahiler kiri. Ukuran dan bentuk jantung dalam batas normal. USG Abdomen dengan kesimpulan parenchymal kidney disease bilateral, efusi pleura bilateral, ascites. Penderita didiagnosa sementara Sesak nafas, Sepsis, HAP Late onset, Hipoalbuminemia, Anemia, DM tipe 2, Susp. Sindroma nefrotik

\section{PERKEMBANGAN PENDERITA}

Perjalanan penyakit dibagi menjadi 3 tahap:

1. Penegakan diagnosis

a. HAP late onset ditegakkan berdasarkan adanya infiltrat yang progresif di parakardial dan suprahiler kiri ditambah adanya keluhan batuk makin memberat disertai dahak yang purulen dengan peningkatan leukosit. Penderita juga dilakukan pemeriksaan pewarnaan sputum gram serta kultur dan sensitivitas sputum aerob.

b. Sepsis ditegakkan berdasarkan adanya gejala SIRS dengan adanya sumber infeksi di paru, lalu dilakukan pemeriksaan kultur darah aerob.

c. DM tipe 2 ditegakkan dengan adanya riwayat DM selama $>5$ tahun disertai adanya glukosuri, ketonuri. Dilakukan pemeriksaan GDP, GD2JPP, HbA1C.

d. Kecurigaan terhadap sindroma nefrotik belum dapat disingkirkan oleh karena didapatkan edema anasarka, hipoalbuminemia dan proteinuria. Untuk mengonfirmasi, akan dilakukan pemeriksaan profil lipid dan protein esbach. 


\section{SEQUANCE OF EVENT}

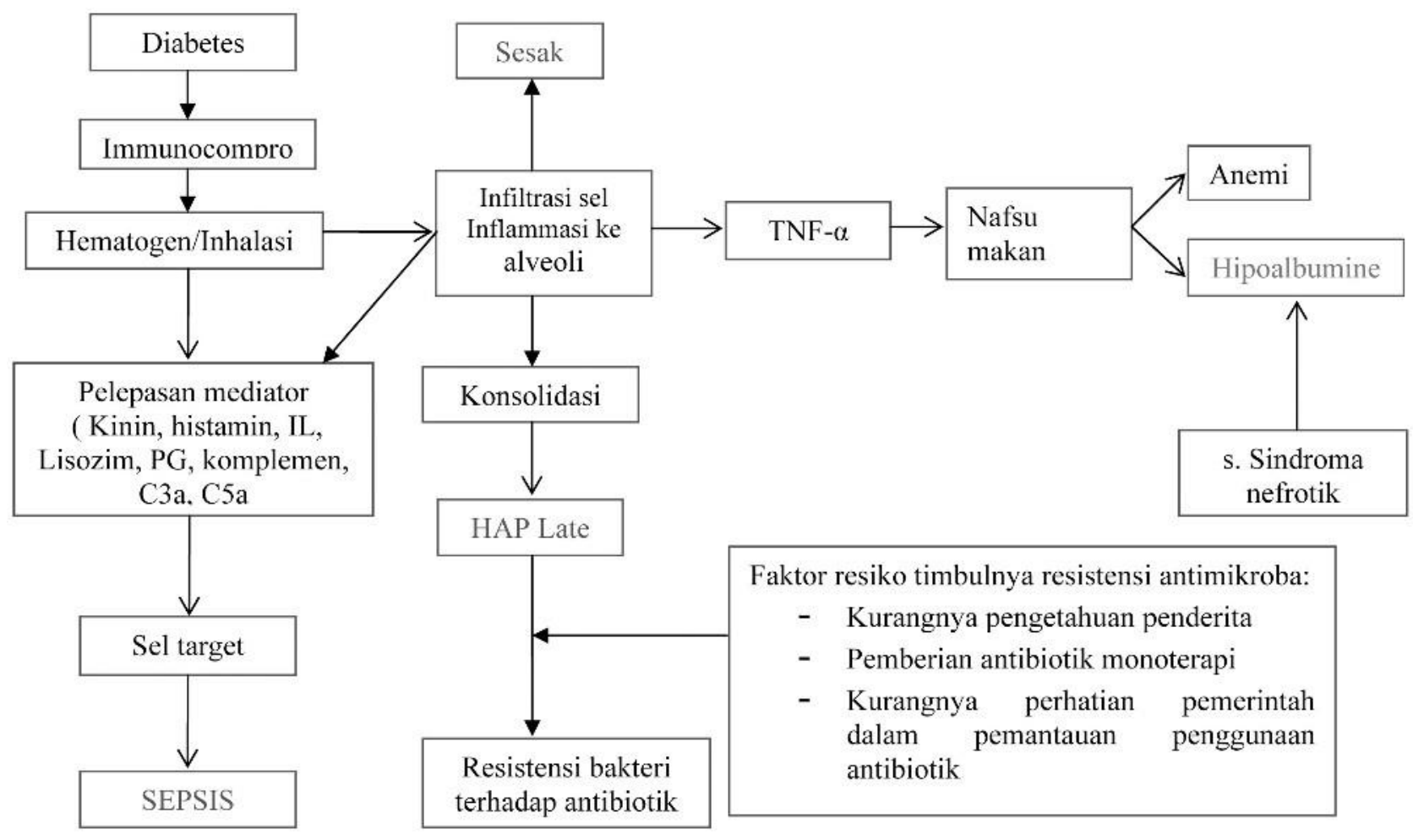

2. Penanganan selama rawat inap

Untuk penanganan sepsis, dilakukan rehidrasi dan balans cairan dengan menyeimbangkan input cairan $=$ produksi urin $+500 \mathrm{cc}$. Penyebab Dari sepsis diduga oleh karena Hospital Acquired Pneumonia (HAP)late onset.

Penderita dirawat di RPI Paru dan mendapat terapi antibiotik empiris meropenem $3 \times 1$ gram dan levofloxacin drip $1 \times 750 \mathrm{mg}$ sambil menunggu hasil kultur. Dalam perjalanannya penderita dirawat bersama dengan departemen penyakit dalam divisi endokrin dan nefrologi serta departemen rehabilitasi medik. Divisi endokrin mendiagnosis penderita dengan DM tipe 2 tanpa tanda-tanda KAD. Divisi nefrologi mendiagnosis penderita sebagai suspek sindroma nefrotik. Penderita juga telah dikonsulkan ke departemen kardiologi dengan diagnosis CPCD masih belum dapat disingkirkan dengan saran ekokardiografi jam kerja. Divisi endokrin memberikan terapi injeksi novorapid $3 \times 4$ unit subkutan. Divisi nefrologi memberikan terapi captopril $3 \times 12,5 \mathrm{mg}$, injeksi furosemid $2 \times 1$ ampul dan KSR $2 \times 1$ tablet. Hasil kultur sputum adalah Pseudomonas aeruginosa dengan resisten terhadap semua antibiotik yang diujikan. Hasil ekokardiografi masih dalam batas normal. Hasil protein esbach 4,4 gram/24 jam.

3. Monitoring

Evaluasi DL dan CXR post antibiotik meropenem dan levofloxacin selama 8 hari didapatkan peningkatan leukosit menjadi 18.300 dengan klinis penderita

yang menetap. Merujuk pada hasil kultur yang menunjukkan resistensi meropenem dan levofloxacin, maka diputuskan untuk mengganti dengan antibiotik Ceftazidime $3 \times 1$ gram selama 4 hari, di mana ceftazidime tidak diuji kepekaannya. Evaluasi setelah 4 hari pemberian antibiotik, didapatkan peningkatan leukosit menjadi 25.900 dengan gambaran foto toraks didapatkan efusi pleura kanan serta analisis cairan pelura didapatkan efusi pleura transudat yang disebabkan oleh karena hipoalbumin. ${ }^{1,6}$ Selanjutnya diputuskan untuk mengganti antibiotik yang hasil kulturnya intermediate, yaitu cefoperazone-sulbactam $3 \times 1$ gram serta perbaikan albumin dengan drip albumin $20 \% 100 \mathrm{cc}$. Evaluasi setelah pemberian ceftazidime dan cefoperazone-sulbactam di mana klinis meburuk dengan leukositosis yang tidak membaik, diputuskan untuk menggunakan kembali antibiotik meropenem dan levofloxacin, dengan pertimbangan selama pemakaian antibiotik tersebut di ROI, klinis penderita berangsurangsur membaik. Pemberian antibiotik ini selama 9 hari sambil menunggu hasil kultur sputum yang baru. Evaluasi setelah 9 hari pemberian meropenem dan levofloxacin didapatkan penurunan leukosit menjadi 16.800, akan tetapi tidak ada perbaikan secara klinis dan radiologis.

Hasil kultur terbaru keluar dengan hasil kuman Pseudomonas aeruginosa yang resisten terhadap semua antibiotik. Setelah evaluasi dengan antibiotik meropenem dan levofloxacin tidak ada perbaikan 
secara klinis dan radiologis, maka diputuskan untuk memberi antibiotik yang tidak diuji kepekaannya, yaitu piperacillin-tazobactam $3 \times 1$ gram. Evaluasi setelah pemberian piperacillin-tazobactam selama 7 hari didapatkan penurunan leukosit menjadi 15.400 dengan klinis dan radiologis yang membaik dan edema keempat anggota gerak berkurang setelah albumin terkoreksi $(2,2)$ serta infiltrat pneumonia yang jauh berkurang. Hipoalbuminemia pada penderita ini kemungkinan disebabkan oleh komplikasi dari diabetes melitus, sedangkan sindroma nefrotik masih belum memenuhi kriteria pada penderita ini, sehingga diagnosis penderita ini adalah DM+nefrotic stage. Untuk penanganannya diberikan captopril $3 \times 12,5 \mathrm{mg}$. Mengenai diabetes pada penderita ini diberikan injeksi novorapid $3 \times 4$ unit subkutan dan injeksi humulin N 6 unit pagi hari subkutan. Kondisi penderita baik, kemudian diputuskan untuk memulangkan penderita dengan tindak lanjut kontrol di poli paru, poli endokrin dan poli nefrologi.

\section{PEMBAHASAN}

Pneumonia merupakan suatu keradangan paru yang disebabkan oleh mikroorganisme baik bakteri, virus, jamur, parasit. Angka kejadian pneumonia di Indonesia berkisar Antara 5-35\% dengan angka mortalitas mencapai $20-25 \%{ }^{6}$

Berdasarkan klinis dan epidemiologis, pneumonia diklasifikasikan menjadi lima, yaitu CAP (Community Acquired Pneumonia), HAP (Hospital Acquired Pneumonia), pneumonia aspirasi, pneumonia oportunistik, VAP (Ventilator Ascociated Pneumonia). Pada penderita ini didiagnosis dengan HAP. HAP merupakan suatu bentuk pneumonia yang terjadi $\geq 48$ jam setelah masuk rumah sakit. HAP dibedakan menjadi HAP early onset dan HAP late onset. HAP late onset jika kejadian pneumonia $\geq 5$ hari. ${ }^{6,7}$

HAP/pneumonia nosokomial dapat disebabkan oleh kuman MDR (Multiple Drug Resistance) maupun non MDR. Contoh kuman MDR salah satunya adalah Pseudomonas aeruginosa. Faktor risiko kuman MDR pada HAP antara lain adalah pemakaian antibiotik dalam 90 hari terakhir, dirawat di rumah sakit $\geq 5$ hari, tingginya frekuensi resisten antibiotik di masyarakat atau di rumah sakit tersebut, penyakit imunosupresi dan atau pemberian imunoterapi. ${ }^{8}$

\section{Tata laksana HAP/VAP onset dini dan onset lanjut}

Terapi antibiotik awal secara empirik untuk HAP/VAP pada penderita tanpa faktor risiko patogen MDR. Onset dini dan semua derajat penyakit (mengacu ATS/IDSA 2004) dapat dilihat pada Tabel 1 dan Terapi antibiotik awal secara empirik untuk HAP/VAP untuk semua derajat penyakit pada penderita dengan onset lanjut atau terdapat faktor risiko patogen MDR (mengacu ATS/IDSA 2004) dapat dilihat pada Tabel 2.
Tabel 1. Terapi Antibiotik Awal pada Penderita Tanpa Faktor Risiko Patogen MDR

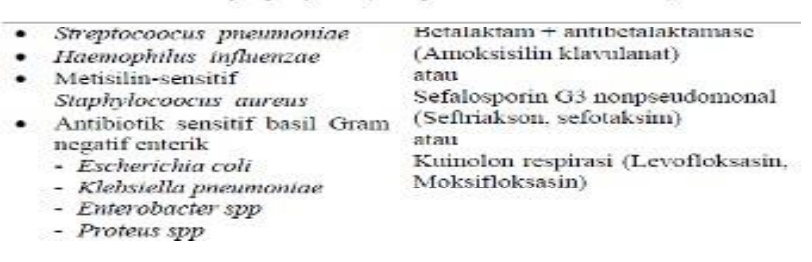

Tabel 2. Terapi Antibiotik Awal Pada Penderita Terdapat Faktor Risiko Patogen MDR

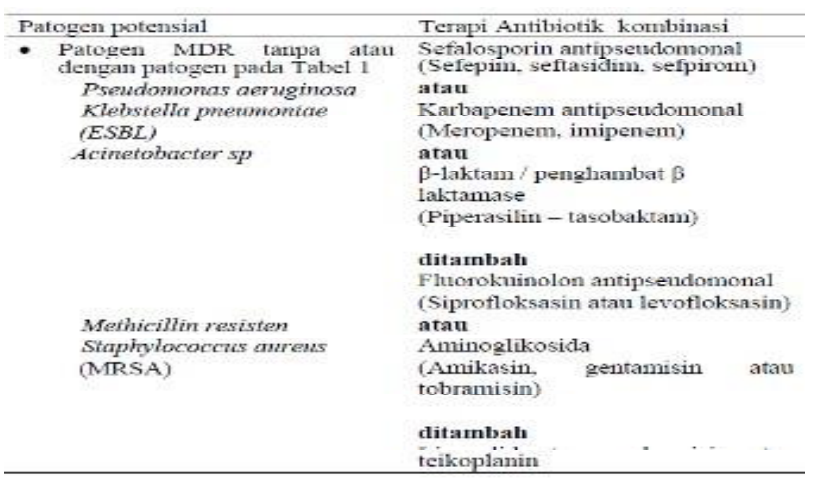

\section{Resistensi Antibiotik}

Antibiotik yang pertama kali ditemukan oleh Paul Ehlrichtahun 1910, sampai saat ini masih menjadi obat andalan dalam penanganan kasus-kasus penyakit infeksi. Pemakaiannya selama 5 dekade terakhir telah mengalami peningkatan yang signifikan, hal ini tidak hanya terjadi di Indonesia tetapi juga menjadi masalah di negara maju seperti Amerika Serikat. The Center for Disease Controland Prevention di Amerika Serikat menyebutkan terdapat 50 juta peresepan antibiotik yang tidak diperlukan (unnescecery prescribing) dari 150 juta peresepan setiap tahun. Ketika digunakan secara tepat, antibiotik memberikan banyak manfaat. Namun bila dipakai atau diresepkan secara tidak tepat dapat menimbulkan kerugian yang luas dari aspek kesehatan, ekonomi bahkan untuk generasi mendatang. Munculnya kuman-kuman patogen yang resisten terhadap satu (antimicrobacterial resistance) atau beberapa jenis antibiotik tertentu (multiple drug resistance) sangat menyulitkan proses pengobatan. ${ }^{9}$

Resistensi didefinisikan sebagai tidak terhambatnya pertumbuhan bakteri dengan pemberian antibiotik secara sistemik dengan dosis normal yang seharusnya atau kadar hambat minimalnya. Sedangkan multiple drugs resistance didefinisikan sebagai resistensi terhadap dua atau lebih obat maupun klasifikasi obat. Sedangkan cross resistance adalah resistensi suatu obat yang diikuti demean obat lain yang belum pernah dipaparkan. ${ }^{10}$

Resistensi terjadi ketika bakteri berubah dalam satu atau lebih kondisi yang menyebabkan turun atau hilangnya efektivitas obat, senyawa kimia atau bahan lainnya yang digunakan untuk mencegah atau mengobati infeksi. 
Bakteri yang mampu bertahan hidup dan berkembang biak menimbulkan lebih banyak kerugian. Kepekaan bakteri terhadap kuman ditentukan oleh kadar hambat minimal yang dapat menghentikan perkembangan bakteri. ${ }^{10}$

Terdapat beberapa faktor yang mendukung terjadinya resistensi, antara lain:

1. Penggunaannya yang kurang tepat (irasional): terlalu singkat, dalam dosis yang terlalu rendah, diagnosis awal yang salah, dalam potensi yang tidak adekuat.

2. Faktor yang berhubungan dengan penderita. Pengetahuan penderita yang salah akan cenderung mewajibkan pemberian antibiotik dalam penanganan penyakit meskipun disebabkan oleh virus. Bahkan penderita membeli antibiotik sendiri tanpa peresepan dari dokter (selfmedication). Sedangkan penderita dengan kemampuan finansial yang rendah seringkali tidak mampu untuk menuntaskan regimen terapi antibiotik.

3. Peresepan: dalam jumlah besar berdampak pada pemborosan biaya dan seleksi resistensi terhadap obatobatan baru. Peresepan meningkat ketika diagnosis awal belum pasti. Klinisi sering kesulitan dalam menentukan antibiotik yang tepat karena kurangnya pelatihan dalam hal penyakit infeksi dan tata laksana antibiotiknya.

4. Penggunaan monoterapi antibiotik.

5. Perilaku hidup sehat: terutama bagi tenaga kesehatan, misalnya mencuci tangan setelah memeriksa penderita atau desinfeksi alat-alat yang akan dipakai untuk memeriksa penderita.

6. Penggunaan di rumah sakit: adanya infeksi endemik atau epidemik memicu penggunaan antibiotika yang lebih masif pada bangsal-bangsal rawat inap terutama di ICU. Kombinasi antara pemakaian antibiotik yang lebih intensif dan lebih lama dengan adanya penderita yang sangat peka terhadap infeksi, memudahkan terjadinya infeksi nosokomial.

7. Penggunaannya untuk hewan dan binatang ternak: antibiotik juga dipakai untuk mencegah dan mengobati penyakit infeksi pada hewan ternak.

8. Promosi komersial dan penjualan besar-besaran oleh perusahaan farmasi serta didukung pengaruh globalisasi, memudahkan terjadinya pertukaran barang sehingga jumlah antibiotik yang beredar semakin luas. Hal ini memudahkan akses masyarakat luas terhadap antibiotika.

9. Penelitian: kurangnya penelitian yang dilakukan para ahli untuk menemukan antibiotik baru.

10. Pengawasan: lemahnya pengawasan yang dilakukan pemerintah dalam distribusi dan pemakaian antibiotik.

Misalnya, penderita dapat dengan mudah mendapatkan antibiotika meskipun tanpa peresepan dari dokter. Selain itu juga kurangnya komitmen dari instansi terkait, baik untuk meningkatkan mutu obat maupun mengendalikan penyebaran infeksi. ${ }^{11}$

Pada penderita ini terjadi resistensi antibiotik multipel disebabkan karena multifaktorial. Faktor penderita, faktor rumah sakit dan faktor stakeholder/pemerintah. Faktor pada penderita adalah kurangnya pengetahuan penderita mengenai penyakit dan tata laksananya. Apabila penderita merasa batuk, pilek, flu, maka penderita langsung membeli obat di antibiotik tanpa periksa dahulu ke dokter. Seperti yang kita ketahui bahwa tidak semua penyakit memerlukan antibiotik. Penggunaan antibiotik yang tidak adekuat dapat meningkatkan risiko resistensi antibiotik. Faktor rumah sakit yang berkontribusi menimbulkan resistensi adalah hanya mendapat antibiotik tunggal (monoterapi) di RS sebelumnya, penggunaan antibiotik yang masif pada bangsal-bangsal rawat inap terutama di ICU/ROI, sempat terputusnya pemberian antibiotik selama 2 hari saat dirawat di ROI, lalainya petugas kesehatan terhadap higienitas seperti masalah kelalaian untuk cuci tangan, kurangya penelitian mengenai resistensi antibiotik di rumah sakit. Faktor stakeholder yang diduga menyebabkan timbulnya resistensi antibiotik adalah kurangnya perhatian pemerintah dalam pemantauan distribusi dan pemakaian antibiotik serta penjualan besar-besaran yang bersifat komersial dari perusahaan farmasi.

\section{Pseudomonas aeruginosa}

Pseudomonas aeruginosa adalah kuman batang gram negatif berukuran $0,6 \times 2 \mu \mathrm{m}$ yang dapat menyebabkan infeksi di paru-paru dengan angka mortalitas mencapai 42-87\%. ${ }^{7}$ Kuman Pseudomonas aeruginosa lebih sering menyebabkan HAP dan jarang menyebabkan CAP. ${ }^{6,7}$ Hal ini sesuai pada penderita ini dengan diagnosis HAP late onset. Kuman ini dapat memproduksi banyak faktor virulen yaitu eksotoksin dan enzim ${ }^{12}$ serta dapat memproduksi biofilm untuk melindungi diri terhadap lingkungan luar termasuk antibodi dan fagositosis sel imun manusia. ${ }^{13}$ Pseudomonas aeruginosa ini merupakan kuman terbanyak yang menyebabkan MDR pada HAP. ${ }^{14}$ Hal ini sesuai pada penderita ini dengan resistensi multipel pada uji kepekaan antibiotik.

Pseudomonas merupakan bakteri gram negatif, bersifat aerob, katalase positif, oksidase positif, tidak mampu mempfermentasi, dapat mengoksidasi karbohidrat, tidak berspora, tidak memiliki selubung/sheat dan mempunyai flagel monotrik sehingga selalu bergerak. ${ }^{15}$

Faktor penyebab kuman ini dapat melawan sistem pertahanan tubuh dan menimbulkan manifestasi adalah pili, sedangkan faktor yang menentukan daya patogen kuman ini adalah eksotoksin A, suatu transferase ADP-ribosa yang berfungsi menghambat sintesis protein eukariota. Gejala sepsis dan syok septik adalah akibat dari adanya endotoksin Pseudomonas aeruginosa. ${ }^{15}$

Keluhan utama pneumonia oleh karena Pseudomonas biasanya adalah sesak nafas, demam dan batuk yang awalnya tidak berdahak, tetapi lama-kelamaan batuk menjadi produktif dengan dahak purulen, berwarna kekuningan atau kehijauan dan kadang-kadang disertai bau busuk. ${ }^{7}$ Gejala klinis pneumonia yang disertai gambaran infiltrat paru yang baru dengan faktor modifikasi yang mengarah ke Pseudomonas merupakan awal dari diagnosis pneumonia yang disebabkan Pseudomonas dan sebagai dasar untuk pemberian antibiotik antipseudomonal. 


\section{Mekanisme Resistensi Antibiotik terhadap Pseudomonas aeruginosa}

Resistensi antibiotik terhadap Pseudomonas akan terjadi melalui beberapa mekanisme, yaitu kuman memproduksi beta laktamase, impermeabilitas membran luar dan upregulasi dari pompa eflux serta pembentukan biofilm. Keempat mekanisme tersebut dapat terjadi secara bersamaan sehingga menyebabkan MDR. ${ }^{17}$

Pseudomonas aeruginosa dapat bermutasi dan memproduksi gen AmpC dalam jumlah besar. Gen AmpC ini memproduksi beta laktamase yang dapat menimbulkan resistensi terhadap antibiotik. Untuk menekan Pseudomonas mutan ini digunakan antibiotik sefalosporin generasi 3 dan ticarcilin-clavulanat. Namun apabila menjadi ESBL, maka kuman mutan tersebut akan menghidrolisis sefalosporin generasi. ${ }^{3,18}$ Untuk mengatasi kuman ESBL, maka digunakan antibiotik golongan karbapenem. Namun beberapa kuman ESBL juga dapat memproduksi metaloenzim. Dengan adanya metaloenzim ini, maka akan timbul resistensi terhadap karbapenem. ${ }^{18}$

Mekanisme resistensi berikutnya adalah melalui pompa eflux. Ini bertujuan untuk memusnahkan/menghilangkan antibiotik sebelum mencapai sasaran pada tubuh kuman. Mekanisme inilah yang menyebabkan Pseudomonas aeruginosa resisten terhadap kuinolon, penisilin antipseudomonal dan sefalosporin generasi. ${ }^{3,19}$

Selain itu, resistensi terhadap seftazidim disebabkan adanya gen pengkode betalaktamase yang dapat menghidrolisis cincin betalaktam pada antibiotik ini sehingga antibiotik golongan ini tidak dapat bekerja menghambat sintesa dinding sel. Selain itu juga dipengaruhi oleh adanya penurunan permeabilitas membran sel bakteri. ${ }^{20}$

DNA girase dihasilkan oleh kuman untuk mempertahankan kromosom kuman dalam keadaan superkoil dan memperbaiki kerusakan pada DNA selama replikasi. Kuinolon bekerja menghambat aktivitas enzim DNA girase sehingga mengganggu replikasi DNA dan menyebabkan kematian sel. Resistensi kuinolon disebabkan oleh mutasi pada satu atau kedua gen sasaran yang mengkode DNA girase dan topoisomerase IV atau modifikasi dari membran luar bakteri yang menyebabkan penurunan permeabilitas obat. Sekitar $20 \%$ dari Pseudomonas aureginosa mungkin resisten terhadap kuinolon. ${ }^{21,22}$

Impermeabilitas membran luar merupakan salah satu mekanisme resisten untuk beberapa jenis antibiotik. Mekanisme resistensi Pseudomonas aeruginosa terhadap karbapenem adalah melalui hilangnya protein membran luar.

Biofilm merupakan suatu struktur yang melapisi bakteri berupa Extracellular polimeric substance (EPGs) yang terdiri dari terutama polisakarida. Pembentukan biofilm dapat menyebabkan kuman tersebut mengalami penurunan kepekaan terhadap antibiotik. ${ }^{23}$ Eradikasi kuman yang memiliki struktur biofilm dengan menggunakan antibiotik harus dengan dosis yang lebih tinggi dibandingkan kuman standar. ${ }^{24}$ Dua alasan utama antibiotik kurang efektif dalam menembus sel-sel pembentuk biofilm adalah karena sel pembentuk biofilm lambat atau bahkan tidak berkembang. Alasan kedua adalah terdapat pengurangan penetrasi antibiotik melalui lapisan biofilm, karena alginat, konstituen utama dalam biofilm, berperan penting sebagai pelindung. ${ }^{21}$

\section{Pencegahan Resistensi Antibiotik}

Ada beberapa usaha yang dapat dilakukan dalam upaya pencegahan resistensi antibiotik, antara lain:

- Pemberian antibiotika kombinasi dalam pengobatan infeksi. Hal tersebut berdasarkan asumsi bahwa bakteri akan lebih sulit membuat dirinya resisten terhadap 2 antibiotik yang bersamaan menyerangnya. Contohnya adalah golongan penisilin diberikan bersamaan dengan betalaktamase inhibitor. Kombinasi obat juga bertujuan untuk menurunkan toksisitas

- Antibiotik dikombinasikan dengan senyawa yang menyerang mekanisme biokimiawi yang menyebabkan bakteri resisten. Contohnya adalah karena siprofloksasin menginduksi suatu pathway bakteri yang meningkatkan kejadian mutasi, sehingga jika gen yang bermutasi dinonaktifkan maka bakteri akan tetap sensitif terhadap siprofloksasin

- Pemakaian tes sensitivitas yang cepat dan akurat sehingga memberi kesempatan untuk memilih antibiotik yang cepat. Contoh tes tersebut adalah reaksi warna, PCR, atau analysis microarray dengan prinsip seperti southern blot dengan probe berasal dari masing-masing gen resisten tetapi memakai indikator sistem antigen antibodi yang cepat.

- Pembuatan vaksin. Cara ini memerlukan data genom dari organisme yang merupakan sumber target dari vaksin. Pada umumnya target penting adalah protein permukaan dari bakteri yang merupakan komponen utama dari vaksin karena langsung berhubungan dengan sistem imun dari tubuh manusia. Saat ini telah dikembangkan vaksin untuk bakteri yang resisten terhadap antibiotik. Pada strategi ini vaksin berisi protein bakteri yang dapat memompa antibiotik keluar dari sel bakteri. Oleh karena itu dengan vaksin tersebut, tubuh seseorang akan mengembangkan respons imun terhadap bakteri yang resisten sehingga bakteri akan dihancurkan.

- Berhubungan dengan kebijakan rumah sakit. Penderita yang terinfeksi bakteri resisten harus diisolasi, kewajiban cuci tangan bagi dokter dan tenaga medis lainnya, menghindari penulisan resep antibiotik bila dipandang tidak perlu, rumah sakit memonitor pemakaian antibiotik dan mengawasi resep yang memakai antibiotik. ${ }^{25,26}$

\section{Penatalaksanaan Bakteri dengan Resistensi Antibiotik Multipel}

Dengan menggunakan pedoman penatalaksanaan HAP late onset yang sudah tersedia, dapat diberikan terapi antibiotik empiris. Terapi empiris merupakan terapi awal 
di mana antibiotik diberikan atas dugaan kuman penyebab dari keadaan infeksi tersebut. Dugaan ini didasarkan pada peta kuman setempat (educated guess). Bila terjadi keadaan infeksi berat yang mengancam jiwa, terapi empiris dapat menggunakan antibiotik berspektrum luas yang bisa mencakup semua kemungkinan kuman penyebab infeksi, bahkan terkadang menggunakan kombinasi antibiotik. Bila identifikasi kuman dan uji kepekaan telah diketahui, maka dilakukan terapi definitif sesuai kuman yang didapat, menggunakan antibiotik yang paling sederhana dengan spektrum yang paling sempit. ${ }^{27}$

Pada penderita ini terapi empiris yang diberikan adalah meropenem $3 \times 1$ gram kombinasi dengan levofloxacin $1 \times 750 \mathrm{mg}$ oleh karena kondisi penderita yang sepsis. Pemberian antibiotik empiris dilakukan sampai keluar hasil kultur sputum yang menunjukkan resistensi antibiotik multipel. Oleh karena hasil kultur tidak dapat memberikan informasi yang adekuat mengenai pemberian terapi definitif, maka terapi definitif menggunakan pola kuman dan terapi antibiotik setempat yang dikeluarkan oleh departemen mikrobiologi klinik.

Dari data mikrobiologis sputum mengenai bakteri dan tes uji kepekaan antibiotik, didapatkan bahwa bakteri penyebab pneumonia terbanyak adalah Klebsiella pneumonia yang diikuti oleh Streptococcus non haemolyticus dan Pseudomonas aeruginosa. Sedangkan data uji kepekaan antibiotik terhadap Pseudomonas yang paling sering menunjukkan sensitif adalah ceftazidime lalu berturutturut diikuti oleh meropenem, cefoperazone-sulbactam, imipenem, cefepime, piperacillin-tazobactam, dst. Dari antibiotik yang disebutkan tadi, didapatkan bahwa semuanya resisten kecuali cefepime dan piperacillin-tazobactam, di mana keduanya tidak diuji kepekaannya. Pada penderita ini diputuskan untuk menggunakan piperacillin-tazobactam.

\section{KESIMPULAN}

Telah dilaporkan kasus seorang penderita laki-laki, 45 tahun, pekerjaan pedagang, suku jawa dengan HAP late onset dan sepsis dengan komorbid berupa DM tipe 2 dan nephrotic stage dengan komplikasi hipoalbuminemia dan anemia. Keluhan yang dirasakan penderita adalah sesak, batuk dengan dahak purulen kehijauan yang disertai bengkak di tangan dan kaki.

Dari pemeriksaan fisik didapatkan inspeksi dan palpasi masih simetris, perkusi masih sonor serta suara nafas masih vesikuler. Namun didapatkan suara tambahan ronki di seluruh lapangan paru kanan dan 2/3 bawah paru kiri tanpa disertai wheezing.

Dari pemeriksaan laboratorium didapatkan leukositosis, hipoalbuminemia dan dari foto toraks didapatkan infiltrat baru di parahiler dan suprahiler kiri. Hasil kultur sputum ditemukan kuman Pseudomonas aeruginosa yang resisten terhadap semua antibiotik yang diujikan.

Perkembangan penderita mendapat pergantian antibiotik sebanyak tiga kali dan antibiotik terakhir yaitu piperasilin-tazobaktam berdasarkan peta kuman yang dikeluarkan oleh departemen mikrobiologi klinik dapat memperbaiki penderita baik secara klinis dan radiologis serta laboratoris.

\section{DAFTAR PUSTAKA}

1. WHO, Drug and therapeutic committees. A practical guide. Departement of essential drugs and medicines policy. Geneva, Switzerland. 2003.

2. Lestari wulan, Zubril nasrul, A. almahdy, Darwin deswinar. Studi penggunaan antibiotik berdasarkan system ATC/DDD dan kriteria gyysens. RSUP. Dr. M. Djamil/Universitas Andalas, Padang. 2011.

3. Peraturan Menteri Kesehatan Republik Indonesia Nomor 2406/ Menkes/PER/XII/2011. Tentang pedoman umum penggunaan antibiotik. Menteri Kesehatan Republik Indonesia. 2011.

4. Kementerian Kesehatan Republik Indonesia. Pedoman pelayanan kefarmasian untuk terapi antibiotik. 2011.

5. H. yulia. Pola resistensi antibiotik. Fakultas Kedokteran Universitas Indonesia. 2009.

6. Pneumonia Komuniti, Pedoman Diagnosis dan Penatalaksanaan di Indonesia. Perhimpunan Dokter Paru Indonesia, 2003.

7. Shigeki F, Hsin Y S, Victor L, Jeremy AW. Pneumonia due to Pseudomonas aeruginosa Part I: Epidemiology, Clinical Diagnosis and Source. Chest. 2011; 139(4): 909-919.

8. Pneumonia nosokomial, Pedoman Diagnosis dan Penatalaksanaan di Indonesia, Perhimpunan Dokter Paru Indonesia 2003.

9. Utami Eka Rahayu. Antibiotika, Resistensi, dan Rasionalitas Terapi. Sainstis volume 1, Nomor 1, April-September 2012.

10. Bari S.B., Mahajan B.M., Surana S.J., Resistance to antibiotic: A challenge in chemotherapy. Indian journal of pharmaceutical education and research 2008.

11. Keputusan Menteri Kesehatan tentang standard pelayanan farmasi di Rumah Sakit No. 1197/Menkes/SK/X/2004.

12. Sadikot RT, Blackwell TS, Christman JW, Prince AS. Pathogen-host interactions in Pseudomonas aeruginosa pneumonia. Am J Respir Crit Care Med. 2005; 171(11): 1209-1223.

13. Ma L, ConoverM, Lu H, Parsek MR, Bayles K, Wozniak DJ. Assembly and development of the Pseudomonas aeruginosa biofilm matrix. PloS Pathog. 2009; 5(3): e1000354.

14. Goossens H. Susceptibility of multi-drug-resistant Pseudomonas aeruginosa in intensive care units: results from the European MYSTIC study group. Clin Microbial Infect. 2003; 9(9): 980-983.

15. Balcht, Aldona \& Smith, Raymond (1994). Pseudomonas aeruginosa: Infections and Treatment. Informa Health Care. pp. 83-84.ISBN08247-9210-6

16. Flanagan JL, Brodie EL, Weng L et al. Loss of bacterial diversity during antibiotic treatment of intubated patients colonized with Pseudomonas aeruginosa. J Clin Microbiol. 2007; 45(6): 19541962.

17. Mesaros N, Nordmanss P, Plesiat P, et al. Pseudomonas aeruginosa: resistance and therapeutic options at the turn of the new millenium. Clin Microbial Infect. 2007; 13(6): 560-578.

18. Walsh TR. Clinically significant carbapenemases: an update. Curr Opin Infect Dis. 2008; 21(4): 367-371.

19. Poole K. Aminoglycoside resistance in Pseudomonas aeruginosa. Antimicrob Agents Chemother. 2005; 49(2): 479-487.

20. Dambrava PG, Torres A, Valles X et al. Adherence to guidelines empirical antibiotic recommendations and community-acquired pneumonia outcome. Eur Respir J. 2008;32(4): 892-901.

21. Ishida $H$, Ishida $Y$, Kurosaka $Y$, Otani T. In vitro and in vivo activities of Levofloxacin against biofilm-producing Pseudomonas aeruginosa. J Antimicrob Chemother. 1998; 42(7): 1641-1645.

22. Karlowsky JA, Kelly LJ. Thornsberry C et al; The surveillance network. Susceptibility to fluoroquinolone among commonly isolated gram negative bacili in 2000. TRUST and TSN data for United States. Tracking resistance in the United States today. Int J Antimicrob Agents. 2002;19(1): 21-31 
23. Hoyle BD,Wong CKW, Costerton JW. Disparate efficacy of tobramycinon Ca_2-, Mg_2-, and HEPES-treated Pseudomonas aeruginosa biofilms.Can J Microbiol 1992; 38: 1214-8.

24. Ceri H, Olson ME, Stremick C, et al. The Calgary biofilm device: newtechnology for rapid determination of antibiotic susceptibilities of bacterialbiofilms. J Clin Microbiol 1999; 37: 1771-6.

25. Kar A. Medical chemistry. New age international publishers. 2007.
26. Kuswandi. Identifikasi mutan-mutan Klebsiella pneumonia yang resisten terhadap antibiotika BRL 41897A dengan metode Southern Blot. Majalah Farmasi Indonesia. 2002; 13(4): 192-5.

27. Herdiman T.P, Suhendro, Djoko W.S. Penggunaan sefalosporin oral pada infeksi komunitas. Current treatment in internal medicine 2000. Jakarta. Pusat Informasi dan Penerbitan Departemen Ilmu Penyakit Dalam FKUI. 2000: 119-24. 